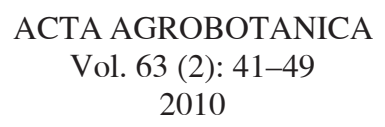

\title{
ECOLOGICAL ADAPTATIONS OF THE FLORAL STRUCTURES OF Galanthus nivalis L.
}

\author{
Elżbieta Weryszko-Chmielewska, Mirosława Chwil
}

\author{
Department of Botany, University of Life Sciences, Akademicka 15, 20-950 Lublin, Poland \\ e-mail: elzbieta.weryszko@up.lublin.pl
}

Received: 15.07.2010

\section{Abstract}

The structure of the flowers of Galanthus nivalis shows adaptations to early spring flowering conditions as well as adaptations to entomogamy. The tepals produce colour marks and odorous substances. The aim of the present study was to determine the micromorphology and anatomy of tepals, in particular in the regions comprising colour marks which, in accordance with the literature data, emit essential oils.

Examination was performed using light, fluorescence, and scanning electron microscopy. Large protrusions, corresponding to the location of the green stripes, were found to occur on the adaxial surface of the inner tepals. The epidermal cells in this part of the tepals produce a cuticle with characteristic ornamentation as well as numerous stomata with well-developed outer cuticular ledges. The wide opening of many stomata is evidence of high activity in this area. The fluorescence microscopy images confirm the high activity of the epidermis (scent emission), on both sides of the tepals, as well as of the chloroplast-containing mesophyll. In the abaxial epidermis, there were observed different-sized papillae that also participated in essential oil secretion.

The polarization of the epidermal cell protoplasts, large cell nuclei, and the presence of large vacuoles with heterogeneous contents in the peripheral part of the cells correspond to the structural features of the tissues emitting odorous compounds in flowers - osmophores. In freshly opened flowers, the mesophyll of the central part of the perianth segments was composed of several cell layers, whereas in older flowers large air ducts formed, which are adaptations to environmental thermal conditions.

Key words: Galanthus nivalis, tepals, micromorphology, anatomy, osmophores

\section{INTRODUCTION}

Snowdrop (Galanthus nivalis L., Amaryllidaceae) grows wildly in central and southern Europe, Asia Minor, as well as in the Caucasus (PiękośMirkowa and Mirek, 2007). In Poland snow- drop is found in the south, in Greater Poland (Wielkopolska), and in the Lublin region where the northern boundary of its range runs $\left(\mathrm{Zaj} a \mathrm{C}_{\mathrm{c}}\right.$ and $\mathrm{Zając}$, 2001; W i t k ow s k a - Ż u k, 2008). It was cultivated as an ornamental plant already in mediaeval gardens (M a urizio and Grafl, 1969). In Poland this species is strictly protected (Piękoś-Mirkowa and Mirek, 2006).

Galanthus nivalis L. flowers from February to April (R u tk ow s k i, 2004). In the last two decades of the 20th century, the beginning of flowering of this species was observed in different European countries a dozen or so days earlier than in the previous years of the last century (M a a k and S t o r c h, 1998; R o etzer et al. 2000), while forecasts for the year 2035 predict further acceleration of flowering by 2 weeks (M a a k and S to r c h, 1998).

The perianth consists of white tepals, arranged in groups of 3 in two whorls. The outer tepals are much longer $(25 \mathrm{~mm})$ than the inner ones $(11 \mathrm{~mm})$, which are distinguished by characteristic green marks on their abaxial surface. On the other hand, in the adaxial part of the upper tepals there are green stripes that are nectar guides for insects. K u g l e r (1970) reports that these stripes are also associated with scent emission. Other research shows that an efficient photosynthesis process occurs in the cells of the green area of the tepals, which provides photoassimilates to flowers and developing seeds (A s chan and Pf an z, 2006).

The flowers of G. nivalis provide to insects precious early spring forage. In addition to nectar, they offer valuable pollen to insects. This pollen is a rich source of group B vitamins (K o ch and S ch w ar z, 1956). Bees are the primary pollinators of these flowers (K u g le r , 1970). They form glistening orange pollen loads from the collected pollen of $G$. nivalis (Maurizio and Grafl, 1969). 
Flower development in G. nivalis starts already in autumn, while its continuation and flower pollination take place in early spring. Morphologically developed ovules with embryo sacs were found in flower buds in September (A k h a l k a t s i and G val a d z e, 1992; C h u d z i k et al. 2002).

The special anatomical features of the leaves and tepals of $G$. nivalis should be considered to be its ecological adaptations. Š č e p a n k o v a and $\mathrm{H} \mathrm{u} \mathrm{d} \mathrm{a} \mathrm{k}$ (2004) showed that lysigenous ducts occurred in the leaves, likewise in the central part of the perianth segments. The presence of lipid compounds was found in the mesophyll cell chloroplasts, but no starch grains were shown.

The aim of the present study was to examine the micromorphology and anatomy of the tepals of Galanthus nivalis, with special attention to the chloroplastcontaining regions participating in scent emission.

\section{MATERIALS AND METHODS}

The study of the flowers of Galanthus nivalis L. was conducted in the period 2009 - 2010. The plants were obtained from the Botanical Garden of the Maria Curie-Skłodowska University in Lublin. Flowers were sampled at the initial stage of flowering. Observations were performed on the tissues of the upper whorl of tepals on which colour attractants occurred.

Hand-cut cross sections of tepals were used for initial light microscopy (LM) examination; they were treated with IKI solution or Sudan III to detect the presence of starch and lipids. The analysis of the plant material was also carried out based on permanent slides made from semi-thin sections $(0.7-1 \mu \mathrm{m})$ stained with $1 \%$ toluidine blue 0 with $1 \%$ azur II, prepared in accordance with the method described by $\mathrm{Chw}$ il (2009). The PAS reaction was performed to identify starch.

A Nikon Eclipse 90 i fluorescence microscope was used to locate the physiologically active tissues of the osmophore. The freshly-cut sections were observed using a TRITC filter set with a light wavelength of EX 540/25 and BA 605/55, obtaining red autofluorescence. The fixed sections were examined after the application of auramine.

The micromorphology of the tepal surface was observed in a Tesla BS - 340 scanning electron microscope (SEM), having prepared the microscopic slides according to the method given by $\mathrm{Ch}$ wil (2009).

\section{RESULTS}

\section{Floral morphology}

The outer tepals of Galanthus nivalis open during sunny weather, making the green mark at the tip of the in- ner tepals visible to pollinators (Fig. 1A, E). In the investigated flowers, the green mark surface area was $3.5 \mathrm{~mm}$. The green stripes, located between the vascular bundles, are found on the adaxial surface of the inner whorl of tepals (Fig. 1B, D). The stamens, situated close to the style, initially dehisce at the apex (Fig. 1C), and then towards their bases along a longitudinal slit (Fig. 1C). In the upper part of the ovary, between the bases of the filaments and the style, there is located a discoid nectary that forms a bright layer, contrasting with the green ovary when viewed in longitudinal section (Fig. 1C).

\section{Tepal micromorphology (SEM)}

The adaxial tepal surface shows large protrusions that correspond to the location of the green stripes. The average tepal thickness in the places of these protuberances was $480 \mu \mathrm{m}$, whereas in the depressions $330 \mu \mathrm{m}$. Numerous stomata $\left(64\right.$ per $1 \mathrm{~mm}^{2}$ ) are found on the convex surfaces of the upper half of the tepals (Fig. 2A - E). When viewed by SEM, the epidermal cells in these areas of the perianth segments most frequently have a quadrangular contour, they are equal dimensional and arranged in rows. Their outer walls are convex.

The Amaryllis-type stomata, with an average length of $30 \mu \mathrm{m}$ and an average width of $26 \mu \mathrm{m}$, are partially shielded by the epidermal cells lying nearby. Each stoma is surrounded by $5-6$ epidermal cells. Well-developed outer cuticular ledges are wide open in many stomata, forming a large outer vestibule (Fig. $2 \mathrm{D}, \mathrm{E})$. The wide opening of the guard cells may indicate high physiological activity of these regions, which is probably associated with the emission of odorous compounds. The surface of the cuticle of the adaxial epidermis cells is marked by characteristic ornamentation formed from undulating and tightly packed striae (Fig. 2D, E). But the epidermal cells located in the depressions of the tepals are more elongated and covered by a cuticle with a less complicated pattern (Fig. 2F).

The abaxial surface of the upper parts of the tepals is characterized by the presence of conical papillae with a height of $36-60 \mu \mathrm{m}$, on average $49 \mu \mathrm{m}$ (Fig. 3A - D). Their diameter at the base is approx. $30 \mu \mathrm{m}$. The papillae occur at high density $\left(28\right.$ per $\left.1 \mathrm{~mm}^{2}\right)$. The cell wall surface is covered with a layer of cuticle showing regular striations. Stomata are located between the papillae in some places of the epidermis.

\section{Tepal anatomy (LM)}

The adaxial epidermis is made up of fine cells (Fig. 4A, H), $24-28 \mu \mathrm{m}$ in height. The thickness of the outer wall in these cells reaches $2.5 \mu \mathrm{m}$. The epidermal cell protoplast is polarized; it has a large-sized nucleus situated by the inner wall and a large vacuole with heterogeneous contents located closer to the outer wall (Figs 4I; 5B, D). 

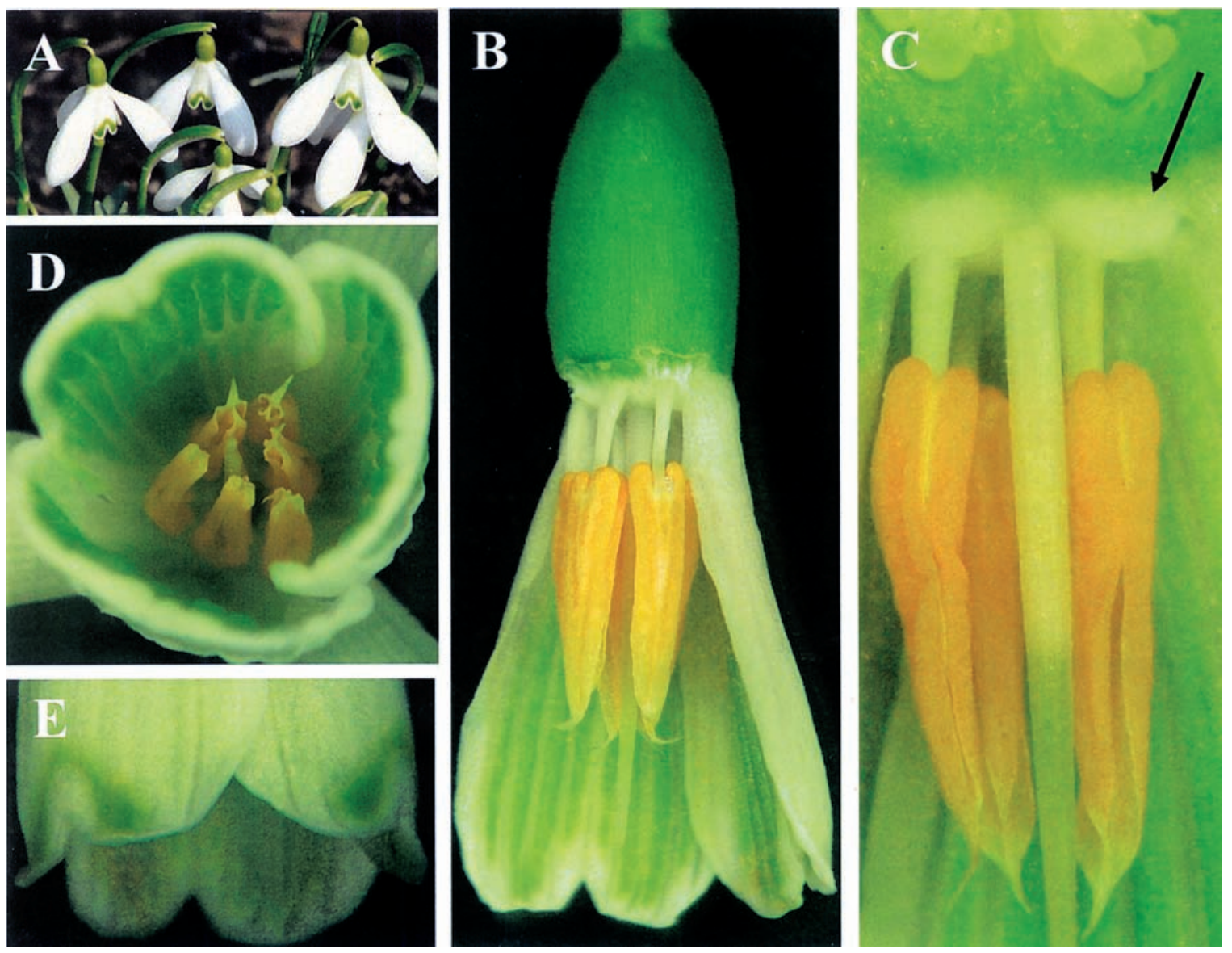

Fig. 1. Flowers of Galanthus nivalis

A - Part of a flowering plant, $\mathrm{x} 0.8$

B - A flower after removal of several tepals, $x$

$\mathrm{C}$ - The longitudinal portion of a flower with a visible nectary (arrow) at the base of the filaments, $\mathrm{x} 12$

$\mathrm{D}$ - The apical part of the stamens in a flower after pollen release, $\mathrm{x} 7$

B, E - Colour marks on the adaxial (B) and abaxial (E) surface of the inner tepals, E - x 8 

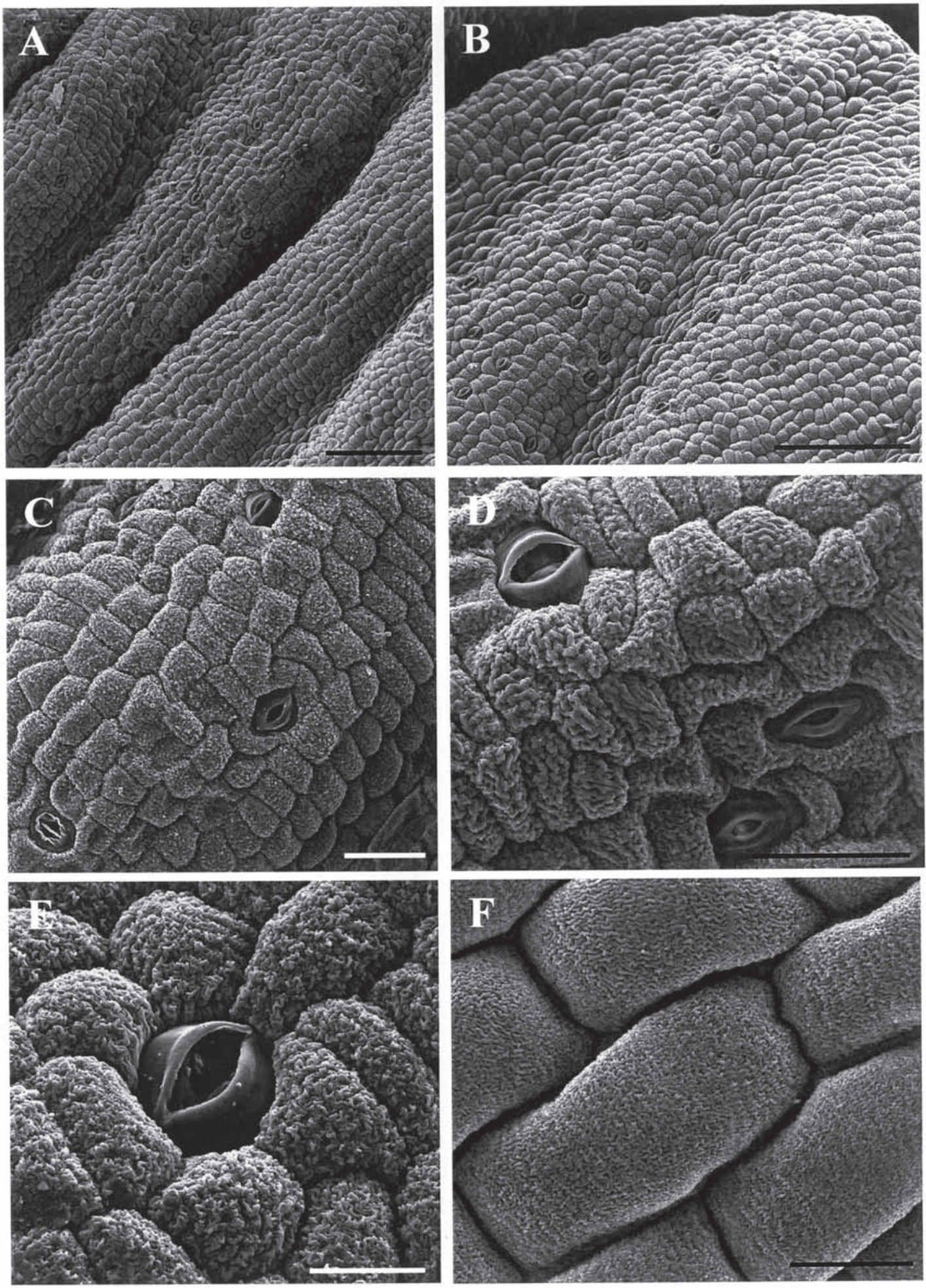

Fig. 2. Adaxial surface segments of the inner tepals (SEM)

A, B - The upper part of the tepals with visible protrusions on the surface and numerous stomata

C, D - Epidermal cells with a strongly folded cuticle and open stomata

E - A stoma with wide open outer cuticular ledges surrounded by epidermal cells with characteristic cuticular ornamentation

F- Epidermal cells from depressions on the tepal surface. Scale bars: A, B $=200 \mu \mathrm{m} ; \mathrm{C}, \mathrm{D}=50 \mu \mathrm{m} ; \mathrm{E}, \mathrm{F}=20 \mu \mathrm{m}$ 

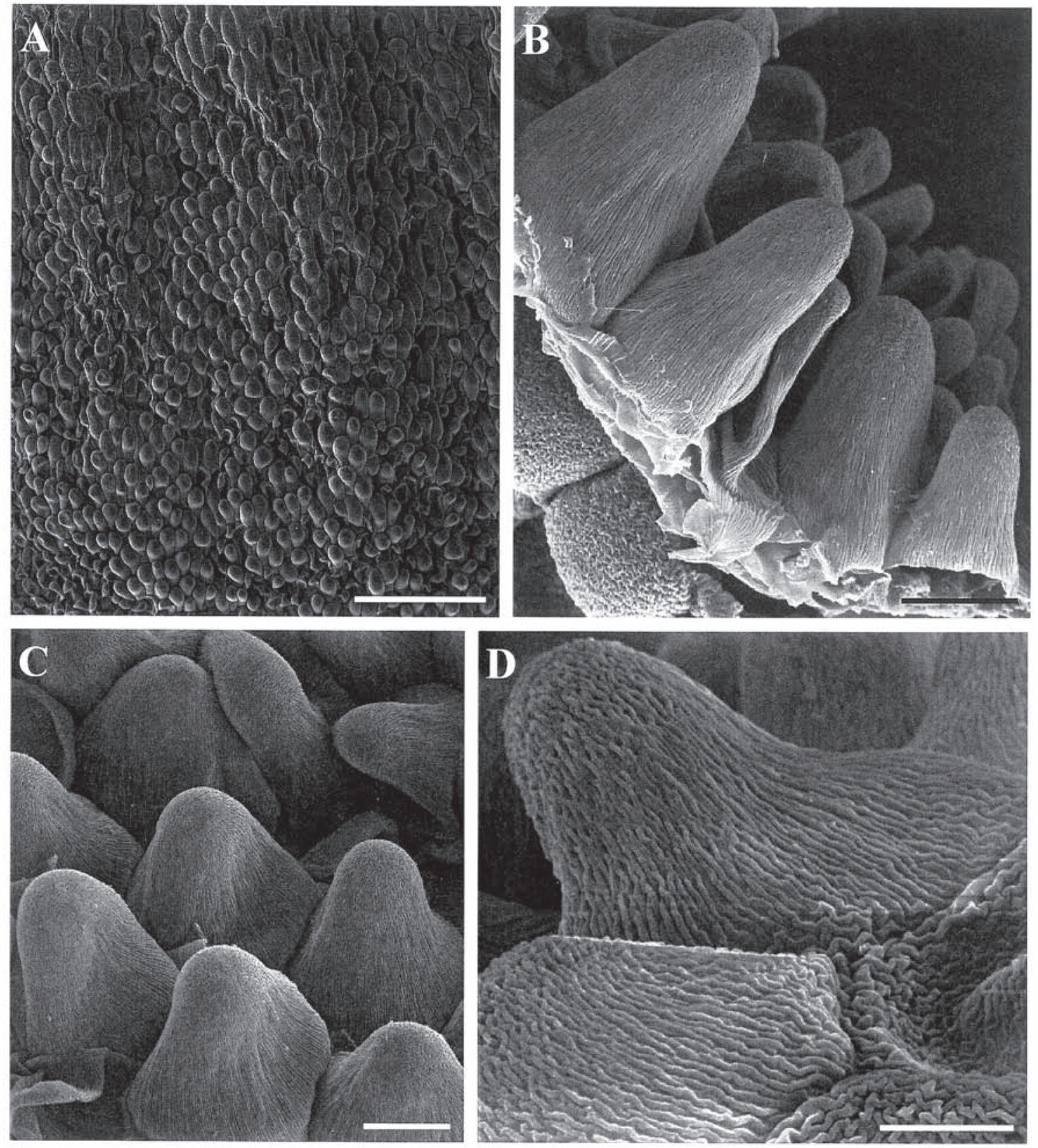

Fig. 3. A - D. Abaxial epidermis cells forming papillae with visible cuticular striae (B, C, D). Scale bars: A=200 $\mu \mathrm{m} ; \mathrm{B}, \mathrm{C}=20 \mu \mathrm{m}$; $\mathrm{D}=10 \mu \mathrm{m}$ 


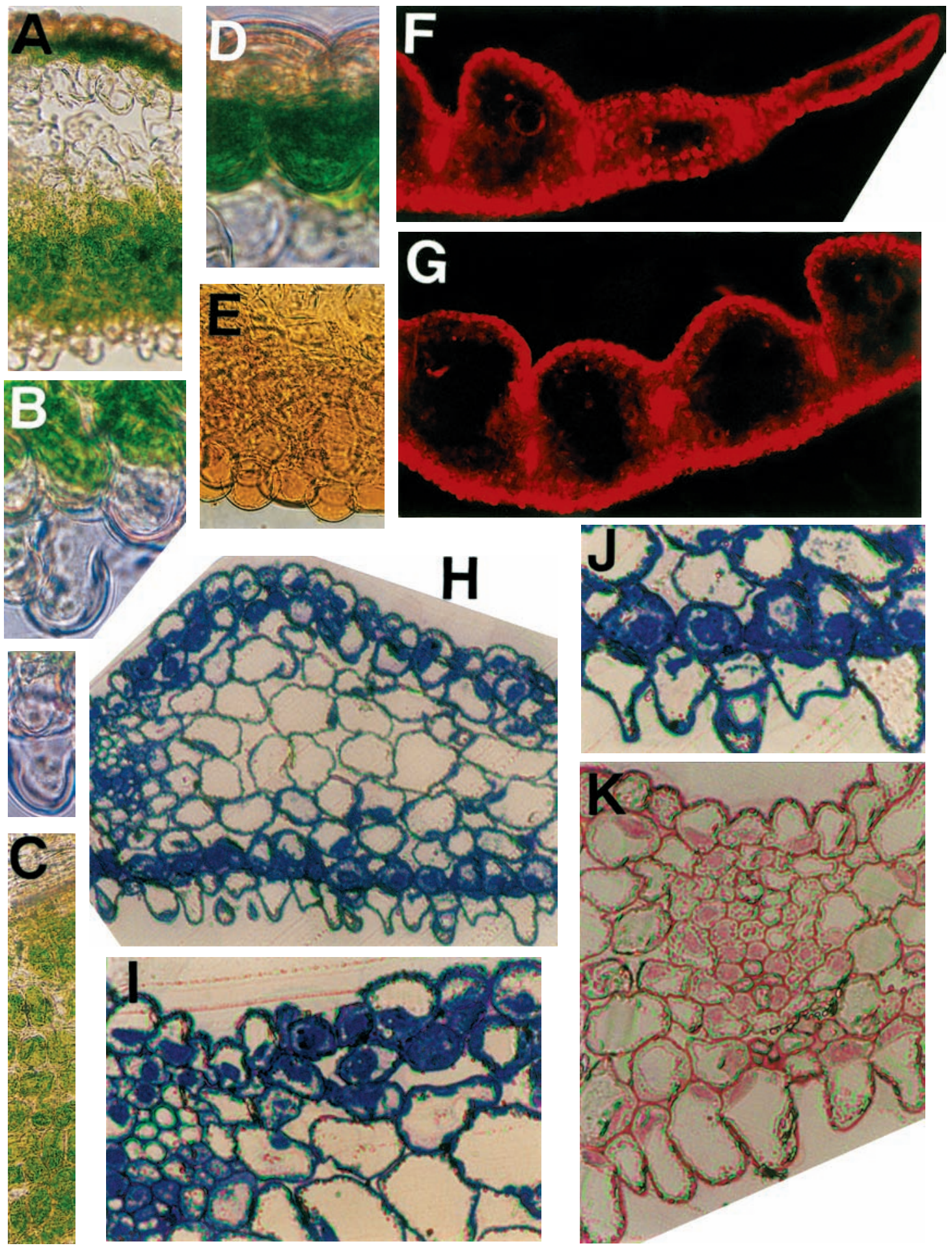

Fig. 4. Cross-sectional portions of the inner tepals and top view of a tepal (C)

A, B, D - Mesophyll layers with chloroplasts in the subepidermal location are visible in fresh specimens,

A, C - x 80, B, D - x 480

E - The abaxial part of a tepal after treatment with IKI, $x-240$

$\mathrm{F}, \mathrm{G}-$ Cross-sectional view of the tepals with visible autofluorescence of some tissues, $\mathrm{x} 60$

$\mathrm{H}-\mathrm{J}-$ Cross-sectional view of the tepal tissues, $\mathrm{H}-\mathrm{x} 120, \mathrm{~J}-\mathrm{x} 240$

$\mathrm{K}$ - The cross-sectional portion of a tepal after application of the PAS reaction, $\mathrm{x}-240$ 

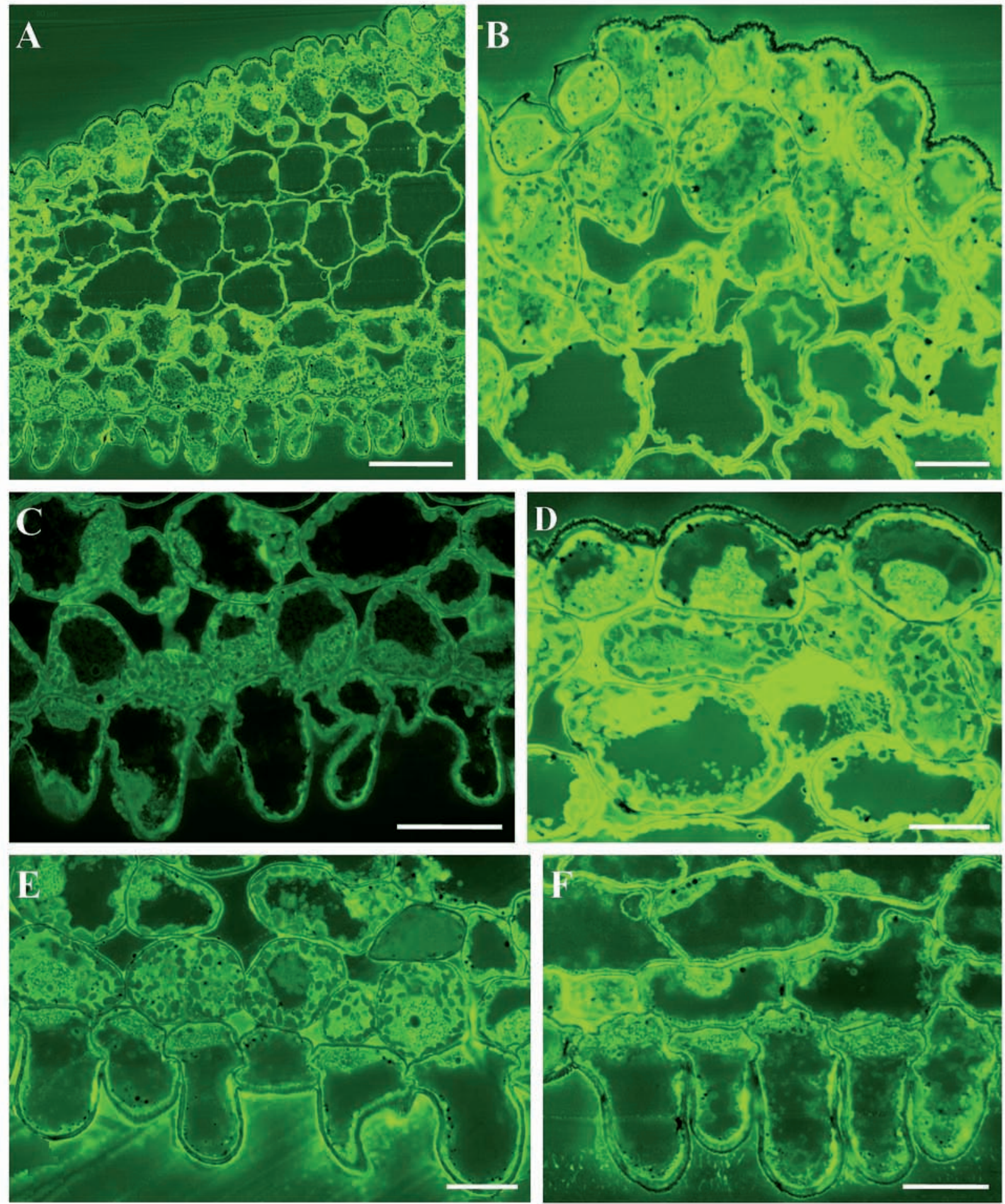

Fig. 5. Cross-sectional portions of the tepals $(\mathrm{A}-\mathrm{F})$ showing fluorescence after treatment with auramine. Scale bars: $\mathrm{A}=50 \mu \mathrm{m}$; $\mathrm{B}-\mathrm{F}=20 \mu \mathrm{m}$ 
The stomata are located slightly below other epidermal cells. Both open and closed stomata were observed. Very small air cavities were found beneath the stomata (Figs 4I; 5B).

The chlorenchyma next to the adaxial epidermis is composed of $1-2$ layers of isodiametric cells (Fig. 4A, C, D). Numerous fine chloroplasts are densely packed in the cytoplasm around the cell walls. The central part of the cells is occupied by large vacuoles (Fig. 5A, B, D). No presence of starch was found in the mesophyll chloroplasts (IKI, PAS) (Fig. 4E, K). The middle part of young tepals is occupied by the parenchyma (3 - 4 layers) (Figs 4H; 5A), whereas in older tepals large air ducts are formed in the areas of the protrusions (Fig. 4A, F, G). The vascular bundles are separated from the adaxial tepal epidermis only by one layer of mesophyll (Fig. 4I, K). The phloem cells contain dense, dark-coloured cell contents.

Papillae of varying height with polarized protoplasts are found in the abaxial epidermis. A thicker layer of cytoplasm, in which large cell nuclei are visible, is formed by the inner walls, while in the apical part a vacuole occupies a large volume (Figs 4B, H, J K; $5 \mathrm{~A}, \mathrm{C}, \mathrm{E}, \mathrm{F})$. The wall thickness at the tip of the papillae is $2-2.5 \mu \mathrm{m}$. Cuticular projections were observed on some papillae, filled with secretion that probably was an essential oil (Fig. 5C). The stomata are located in the epidermis between the papillae. $1-2$ layers of parenchyma with chloroplasts occurred beneath the abaxial epidermis. These plastids were concentrated in great numbers around the cell walls (Fig. 5A, C, E).

Fluorescence microscopy observations of fresh tepal cross-sections, made using a red filter, showed intense fluorescence of the epidermal cells located on both sides of the tepals (Fig. 4F, G), which confirms their activity associated with scent emission. However, intense fluorescence of the cytoplasm in the cells of the outer layers (epidermis, mesophyll) and varying contents in the vacuoles were observed after the perianth tissues (tepals) had been treated with auramine (Fig. 5B, F).

The above described structural features and properties of the epidermal cells of the tepals of Galanthus nivalis show that this tissue, on both sides of the tepals, forms a layer typical of the osmophores emitting odorous substances in flowers.

\section{DISCUSSION}

Adaptations to specific thermal conditions prevailing during the time of flowering of Galanthus nivalis are found in the structure of the tepals of this species. Relatively thick outer walls, with characteristic strongly undulating cuticular ornamentation, were found to occur in the epidermal cells. Large intercellular spaces and a central air duct are present in the parenchyma; they may form an internal ventilation system protecting against low temperature.

Š č e pánk ow a and Huda k (2004) report that the air ducts inside the tepals of $G$. nivalis belong to the adaptive features to early spring growth conditions. They may be a protection of the generative organs against low temperature. As a result of their study on the ultrastructure of the perianth segments of G. nivalis, Š č e pánk ow a and $\mathrm{Hudak}$ (2004) found that amoeboid chloroplasts, containing numerous plastoglobules, occurred in the green parts, likewise in the leaf mesophyll of this species, which was also recognised to be an ecological adaptive trait.

In $G$. nivalis the epidermis of the tepals emitting odorous compounds is made up of cells producing papillae (abaxial surface) and of small isodiametric cells (adaxial surface). The scent-emitting epidermis is accompanied by the parenchyma containing numerous chloroplasts, which probably is the tissue participating in the production of odorous substances. Since the emission of fragrant secretion is short-lived and is associated with the consumption of a large amount of storage compounds, the secretory tissue of the osmophore usually comprises several layers (E s a u, 1973; V o g e 1, 1990). The mesophyll cells of the tepals of G. nivalis do not contain starch in their chloroplasts. But lipids have been found in them (Š č e pán k o w a and $\mathrm{Hudak}, 2004)$. In the case of the osmophore tissues, this trait is found in many plants, which has been recorded by $\mathrm{S} w$ an s on et al. (1980), V o ge 1 (1990), S t pi c z y ń s k a (2001), and W e ry s z k o Chmielewska et al. (2007).

A schan and Pfanz (2006) showed that in the green areas of the tepals of $G$. nivalis intense photosynthesis occurs; its products are supplied to different parts of flowers and developing seeds. The location of the layer of chloroplast-containing mesophyll underneath the epidermis emitting essential oils allows one to think that lipid compounds formed in the chloroplasts are used for the production of odorous compounds.

The data presented by K u g le r (1970) show that the green stripes and the $\mathrm{V}$-shaped green mark, located on the inner tepals of G. nivalis, emit a more intense, but qualitatively similar scent to that produced by other parts of the perianth.

Numerous stomata are found in the adaxial epidermis of a part of the tepals of G. nivalis. They function non-synchronously, since they exhibit different degrees of opening of the cuticular ledges and pores. Vogel (1990) reports that in the tissues emitting odorous compounds intense transpiration occurs during their active emission related to the wide opening of the stomata, which remain closed before the emission and after the release of scent. In many stomata located on the surface of the green stripes in the tepals of 
$G$. n i v a 1 is, we observed well-developed and very wide open outer cuticular ledges, which may be evidence of high physiological activity of the outer tissues. We observed earlier massive cuticular ledges in the stomata of the osmophores of Amorphophallus rivieri (Weryszko-Chmielewska and S t p i c z y ńs k a, 1995).

\section{REFERENCES}

Akhalkatsi M. Sh., Gvaldze G. E., 1992. Seasonal changes in embryo sac ultrastructure in Galanthus nivalis (Amaryllidaceae). Botanicheskii Zhurnal 77 (1): 66-73.

A s c h a n G., Pfanz H., 2006. Why Snowdrop (Galanthus nivalis L.) tepals have green marks? Flora 201: 623-632.

Chudzik B., Śnieżko R., S z a n b J., 2002. Biologia kwitnienia Galanhtus nivalis L. (Amaryllidaceae). / Flowering biology of Galanhtus nivalis L. (Amaryllidaceae). Ann. Univ. Mariae Curie-Skłodowska, EEE Hortic. 10: 1-10 (in Polish).

Chwil M., 2009. Flowering biology and nectary structure of Melisa officinalis L. Acta Agrob. 62 (2): 23-30.

E s a u K., 1973. Anatomia roślin. Państwowe Wyd. Rolnicze i Leśne, Warszawa (in Polish).

Koch A., S chwarz I., 1956. Wirkstoffe der B - Gruppe in der Bienennährung. Insectes Sociaux, 3 (2): 213-228.

Kugler H., 1970. Blútenókologie. Gustar Fischer Verlag, Stuttgart.

Maak K., Storch H. von, 1998. Statistical downscaling of monthly mean air temperature to the beginning of flowering of Galanthus nivalis L. in Nothern Germany. Int. J. Biometeorol. 41 (1): 5-12.

Maurizio A., Grafl I., 1969. Das Trachtpflanzenbuch. Ehrenwirth Verlag, Múnchen.

P i ęk oś- M i rkowa H., M i rek Z., 2006. Rośliny chronione. MULTICO Oficyna Wydawnicza, Warszawa (in Polish).

Rut kow sk i L., 2004. Klucz do oznaczania roślin naczyniowych Polski niżowej. Państwowe Wydawnictwo Naukowe, Warszawa (in Polish).

Š č e pán kowa I., Hudak J., 2004. Leaf and tepal anatomy, plastid ultarstructure and chlorophyll content in $G a$ lanthus nivalis L. and Leucojum aestivum L. Plant Syst. Evol. 243: 211219.

Stpiczyńska M., 2001. Osmophores of the fragrant orchid Gymnadenia conopsea L. (Orchidacea). Acta Soc. Bot. Pol. 70 (2): 91-96.

Swanson E. S., Cunningham W. P., Holman R. T., 1980. Ultrastructure of Glandular Ovarian Trichomes of Cypripedium calceolus and C. reginae (Orchidaceae). Am. J. Bot. 67 (5): 784-789.

Vogel S., 1990. The role of scent glands in pollination: on the structure and function of osmophores. Amerind Publishing Co., New Delhi, India.

Weryszko-Ch mi elew ska E., S t piczýn sk a M., 1995. Osmophores of Amorphophallus rivieri Durieu (Araceae). Acta Soc. Bot. Pol. 64 (2): 121-129.
Weryszko-Chmielewska E., Chwil M., Sawidis T., 2007. Micromorphology and histochemical traits of staminal osmophores in Asphodelus aestivus Brot. flower. Acta Agrobot. 60 (1): 13-23.

Witkowska-Żuk L., 2008. Atlas roślinności lasów. Flora Polski. MULTICO Oficyna Wydawnicza, Warszawa (in Polish).

Zając A., Zając M. (Red.), 2001. Atlas rozmieszczenia roślin naczyniowych w Polsce. Pracownia Chorologii Komputerowej Instytutu Botaniki Uniwersytetu Jagiellońskiego, Kraków (in Polish).

\section{Przystosowania ekologiczne struktur kwiatowych Galanthus nivalis L.}

\section{Streszczenie}

W budowie kwiatów Galanthus nivalis występują adaptacje do warunków kwitnienia wczesną wiosną, jak również przystosowania do entomogamii. Działki okwiatu wytwarzają wskaźniki barwne oraz substancje zapachowe. Celem badań było określenie mikromorfologii oraz anatomii działek okwiatu, zwłaszcza w strefach obejmujących wskaźniki barwne, które zgodnie $\mathrm{z}$ danymi z literatury emitują olejki eteryczne.

Badania przeprowadzono przy użyciu mikroskopii świetlnej, fluorescencyjnej oraz skaningowej elektronowej. Wykazano, że na doosiowej powierzchni wewnętrznych działek występują znaczne uwypuklenia odpowiadające położeniu zielonych prążków. Komórki epidermy tej części działek wytwarzają kutykulę o charakterystycznej ornamentacji i liczne aparaty szparkowe z dobrze rozwiniętymi zewnętrznymi listwami kutykularnymi. Silne rozwarcie wielu aparatów świadczy o dużej aktywności tej strefy. Obrazy uzyskane w mikroskopie fluorescencyjnym potwierdzają dużą aktywność epidermy (emisja zapachu) po obu stronach działek, jak również mezofilu zawierającego chloroplasty. W epidermie abaksjalnej obserwowano różnej wielkości papille, które również uczestniczą w sekrecji olejków eterycznych.

Polaryzacja protoplastów komórek epidermy, duże jądra komórkowe oraz obecność dużych wakuol z niejednorodną zawartością w peryferyjnej części komórek odpowiadają cechom budowy tkanek wydzielających związki zapachowe w kwiatach - osmoforom. W świeżo otwartych kwiatach mezofil centralnej części działek składał się z kilku warstw komórek, natomiast w starszych tworzyły się duże kanały powietrzne, które stanowią adaptację do warunków termicznych środowiska. 
